\title{
Moral and Political Significance of the Term "Virtus" in Plautus' Amphitruo
}

\begin{abstract}
Ahmed FAHMY
Suez canal university

After Hannibal's wars, Rome started its expansion and empire, and there were classes within Roman society ; nobles were known as parents patres whereas the rest of the society were known as plebeians plebs. The ratio of the nobles and the senate was minority if compared to Roman population . There was a general aristocratic idea of the ideal qualities which the virtuous man must have, such as courage virtus ,honour honor, moderation moderatio, fidelity fides, and friendship amicitia.

In this paper the researcher will deal with the moral and political concept of the word courage virtus as regarded by the Roman citizen during the Republican Age, the impact of this term on the political thought in the Roman society, and the connection of this term to other terms, such as nobility noblitas, glory gloria , confidence fides , and pleasure voluptas. ${ }^{(1)}$ It is clear that the Roman republic policy was social ; so the language of policy reflects this concept, especially as all the Romans dealt with political issues through the social perspective. This is certainly reflected through their interest in morality and their commitment to it, the objective which the Roman discipline aimed at in its management of the Roman society without isolating politics from social customs and traditions. ${ }^{(2)}$

Since Ethics are actions, behaviors and words which are consistent with customs and social traditions, the Roman citizen is characterized by his excessive love of home patria and adherence to piety pietas which means commitment to daily ethics towards the state, the society and individuals, as well as the parents and the family , and above all towards the gods, and the commitment to duty and adherence by ancestors' custom mos maiorum,
\end{abstract}

Classical Papers, vol. xi , 2012 


\section{- Moral and Political Significance of "Virtus" in Plautus' Amphitruo -}

In (Tusculanae disputationes, 1,1 ) Cicero presents the features and characteristics which represent the Roman ethics and pride in the ancestors' custom:

quae enim tanta gravitas, quae tanta constantia, magnitudo

animi, probitas , fides, quae tam excellens in omni genere virtus

in ullis fuit, ut sit cum maioribus nostris comparanda.

Really which status, harmony, greatness of soul, honesty, loyalty ,or virtuous courage from any gender in any people, was compared to our ancestors virtues?

The early centuries of the Roman republic witnessed the struggle and internal strife of the Roman plebeians towards political, social and economic conditions . Under these circumstances the plebeians united with aristocrats to form a new aristocracy that was characterized by the word nobilitas, and became political aristocracy. ${ }^{(3)}$

In this regard the researcher will show full explanation of the concept of the Roman courage virtus Romana during the third and second centuries B.C.

The word virtus in the public Roman life differs in its concept from its etymological meaning. Linguistically, it means courage not virtue ; greatest courage is not limited to the fields of war. At the same time it isn't one of the features of brave warriors only, but there are peaceful struggle courage to liberate the country, and the consistency courage on belief whatever happened to the person from violence or persecution. Also there are opinion courage and invitation courage for reformation....etc. This variety also applies to some other terms - as Earl indicated - which were common in the Roman society through the third and second centuries B.C. , such as fides which means fidelity not honesty, and noblitas which means nobility not luxury. ${ }^{(4)}$

Firstly, the Romans glorified and venerated courage virtus ranking it before money virtus ante nummos. ${ }^{(5)}$ So they were interested in applying the courage virtus in their life, because on the one hand it embodied the Roman thought and on the other the Roman ideas were influenced by the Greek stoicism, in its dealing with the term "virtus", whether it means 


\section{Ahmed FAHMY}

courage or virtue , because virtue means excellence especially in courage, which represents the philosophical aspect of the term. ${ }^{(6)}$

In this context Beer asserts that the term of courage virtus is a prominent feature of stoic philosophical thought, and it has a connection to purity and Christian piety, as Cato indicated in his works. ${ }^{(7)}$

On the psychological side, Roman politicians struggled against destructive currents against the Roman courage virtus Romana which clearly appeared in political and military fields, where courage was considered a virtue, in order to achieve victory and get the spoils, which was a moral victory. ${ }^{(8)}$ Courage virtus - as Brown indicated - is considered a condition of leadership by Caesar ; because victory in general depended on two things :courage virtus and counsel consilium $;^{(9)}$ so the veteran leader is the man who combines between virtus and consilium. ${ }^{(10)}$

Politically, the nature of this term shows the obvious Romans' custom towards moral purification, where morality is a mask for society, through it the society keeps its stability. Therefore the Roman classes had courage virtus and established the political side on it ; hence, the political Roman citizen combined between aristocracy nobilitas and courage virtus. ${ }^{(11)}$

It is clear that the verbal derivation of the term virtus represents the nature or the fine character of man vir, such as the word "aging " senectus, which describes the old man senex, and the word " adulthood " iuventus, which describes a youth iuvenis . but the word virtus is distinguished from its equivalent words in that it is more spiritual. In this word virtus we feel invocation, supplication, prayer and meditation, such qualities and features which characterized the Roman citizen more than others from the political point of view. ${ }^{(12)}$

Also, the term virtus " courage " is considered a symbol of eloquence and rhetoric eloquentia; therefore Earl mentioned that the eloquent citizen who doesn't have courage virtus, is like a hired mourner who wears the mourning clothes and praises others but cannot truthfully praise herself. ${ }^{(13)}$

Horace confirms in (Carmina , 3.2) that the term virtus consists of two verbal significations : one is militarism or what we might call 


\section{- Moral and Political Significance of "Virtus" in Plautus' Amphitruo e}

heroism or manhood, and the other comes from the word "incense" tus; it is understood that "man's incense " is his courage. ${ }^{(14)} \mathrm{He}$ also indicates in (Carmina, 3, 2.21 to 22) that one meaning of the term virtus is a kind of sanctification towards the sky, this ascending towards the sky seemed to Horace's audience a symbol which referred to the doctrine. ${ }^{(15)}$

virtus recludens inmeritis mori

caelum negata temptat iter via.

True courage rises of innocents from sloping road to suspending sky.

Earl agrees with Horace in that "courage" virtus is one of the features of manhood making use of the inscription of L. Cornelius Scipio, which describes Barbatus - Scipio's father - as being a courageous man vir fortis, who has the courage to reach glory, and to avoid defeat, which Barbatus' son - Scipio - also has. . $^{(16)}$

Whereas Cicero sees that the concept of "courage" virtus symbolizes eternal fame which flows out of the veins, such as the movement of spirit within the body (Pro Sestio, 143, 9-11): (17)

cogitemus denique corpus virorum fortium magnorum

hominum esse mortale, animi vero motus et virtutis

gloriam sempiternam.

At last we believe that the body of strong great

men is perishable, and the movement of the Spirit

and indeed courage has eternal fame.

Also Sallust was skillful in utilizing the linguistic derivation of the word virtus from the word "man" vir, and in using it in his work (Hist.ampliora.49-50):(18)

estne viris relicui aliud quam

solvere iniuriam aut mori per virtutem?

Is there among men who liberate from injustice

or (keep) the custom of ( his ancestors) through courage?

The Plautine comedy was contemporary to the period of struggle and internal strife of the Roman nobles, which was followed by the war of Hannibal, then the exile of Scipio Africanus ; hence, in this period there 


\section{Ahmed FAHMY \\ was an aristocratic conduct depending on the concept of courage "virtus". ${ }^{(19)}$}

So Plautus' excessive use of customs, ideas and Roman traditions was surrounded by the conception of courage "virtus". he used this term to clarify one of the conceptions of aristocratic thought, he also employed the term in two ways ,on the one hand to comment directly on the sociopolitical side in Rome, and on the other to deepen the comic effect. ${ }^{(20)}$

In the play Amphitruo, Alcumena always takes care of her duty towards her husband and her parents and the gods meum officium facere (v.675). She embodies the character of the Roman wife whom every Roman desires , particularly when she delivers a monologue in the praise of her Roman husband's courage (v. 642 ff.). The monologue's words are not heard from any other Plautine wife. ${ }^{(21)}$

In Amphitruo, Plautus doesn't forget to show his originality and the bravery of his Roman citizens. In ( v. 75 ) he describes the Romans as victors, and advice them that they must have couarge virtus; at the same time he warns them against the meanness or conspiracy ambitio . ${ }^{(22)}$

virtute dixit vos victores vivere, non ambitione .

Also as he said that you live having courage not meanness.

In this verse, which was mentioned in Amphitruo's prologue, Plautus matches between the two words virtus and ambitio. It is clear that without courage, the Romans couldn't achieve great victories at war. This moral role of courage virtus includes in its content the concept of the term fides "fidelity " or "good faith" by which the Roman citizen coexisted with his followers and political companions, In these two terms virtus and fides, justice was achieved.$^{(23)}$ We see this clearly in the courts, particularly in the defense of Cicero for Sestius (68, 3-4), where Cicero used the two words virtus and fides:

L. Ninnio, cuius in mea causa numquam fides virtusque contremuit.

Lucius Ninnio, who did not tremble in my case out of fidelity and courage. 


\section{- Moral and Political Significance of "Virtus" in Plautus' Amphitruo -}

It is notable that Plautus uses the word ambitio in two different meaning associated with the term virtus. When Plautus uses it in the play Amphitruo to mean "conspiracy - meanness", we find him using it in another meaning "ambition" in the play Trinummus, in order to confirm that there is a direct connection between the two words, ambitio and virtus, and in particular in these two passages: ${ }^{(24)}$

Plaut. Trin .(v.1033)

ambitio iam more sanctast, liberast a legibus.

Because there is scared ambition according to custom, unrestricted by the laws.

Plaut. Trin.(v. 642-643)

itan tandem hanc maiores famam tradiderunt tibi tui, ut virtute eorum anteparta per flagitium perderes?

At last, your ancestors handed over this custom for you, Do you destroy the courage of those due to abuse?

It seems that Plautus asserts here that ambition and courage connote ancestors' customs mores maiorum, both of which are symbols of manhood and victory ; so Plautus used to address his citizens in soliloquies as victors who had courage, as it happened in the play Cistellaria (v.197-198): ${ }^{(25)}$

bene valete et vincite virtute vera, quod fecistis antidhac;

Goodbye, win with true courage,

Because you have done it before.

It is clear in the play Amphitruo that the last verses of Alcumena's monologue (v. 652-653) are an excellent example of the praise of courage, virtus in Roman style which reflects self-knowledge:

virtus omnia ín sese habét, omnia ádsunt

bona quém penest vírtus.

Courage includes all things, all good things which are close to the man who is courageous.

While Galinsky sees that the concept of "courage" virtus which Alcumena announced in these previous verses, and the content of these verses :" who has a courage: all good things are close to him" omnia non adsunt bona, 


\section{Ahmed FAHMY}

differs from Amphitruo 's character who is always annoyed and suffers from his bad fortune until the end of the play. ${ }^{(26)}$

But in any case these verses are considered as indication in Plautus to introduce Amphitruo 's character, so after the end of the monologue directly we find Amphitruo walking on stage in a manner of bragger soldier miles gloriosus, in order to glorify and magnify his military courage (v. 656-657):

victis hostibus: quos nemo posse superari ratust, eos auspicio meo atque ductu primo coetu vicimus.

By enemies' defeat: who none can think of their defeat, we have defeated them since the beginning of the attack, under my leadership and my authority.

At the end of Alcumena's monologue, Plautus increases the musical meters and rhetorical repetition, to spiritual elation by courage virtus (v. 648649):

virtus praemium est optimum;

virtus omnibus rebus anteit profecto.

courage is the best reward,

no doubt courage precedes all things.

It is noticeable that Alcumena's monologue had a tragic tendency, in order to show the importance of "courage" for the Roman citizen, especially at war ; something which had a great significance in the light of contemporary political conditions in Rome at that time. ${ }^{(27)}$

Plautus presented for us in Alcumena 's character a description of the Roman mother and wife, and these features and attributes were required by his audience. So we find that in order to show the true meaning of the word "courage" virtus and to persuade his audience of Alcumena 's character, Plautus was interested in showing this word and its interpretation by linking two other words, which are, pleasure voluptas and distress moles ( v. 633 635): ${ }^{(28)}$

Satin parva res est voluptatum in víta atque in aetate agunda praequam quod molestum est? ita cuique comparatum est in aetate hominum; ita divis est placitum, voluptatem ut maeror comes consequatur: 


\section{- Moral and Political Significance of "Virtus" in Plautus' Amphitruo -}

Really is not the issue of the pleasures in life is miniscule compared to distress at that moment? Thus this is what happens in the life of

humans, It is the wish of the gods that pleasure is followed by grief .

In Amphitruo, Alcumena 's character attract our sympathy, because she has courage, loyalty and honor. So Duckworth comments on (v. 640-653) - as mentioned at Philips - saying "The chastity and purity of the soul and emotional tendency are presented in Alcumena by the full Roman meaning , and in particular the complaisance courage of love virtus obsequentiae, which the Romans admired in the qualities of a wife. ${ }^{(29)}$ If Alcumena has talked about her enjoyment and pleasure voluptas with her husband away from adultery, we find her giving up this pleasure against the courage of her husband in the battlefield, where the word "courage "virtus is repeated four times in (v. 648, 649,652,653), and all of them harmonize with the word " pleasure " voluptas since the opening of the song canticum. So it is clear that courage virtus in its content is pleasure, and that courage is a Roman patriotic value ${ }^{(30)}$ through which Amphitruo and his soldiers defeated the Teloboians and (capture ) taking over the town (v.191-192):

id vi et virtute militum victum atque expugnatum oppidum est .

That victory has been come out of the strength and courage of the soldiers in taking over the town.

In the play Miles gloriosus (v. 31-32) when Artotrogus mentions the word "courage" virtutes, it appears that he describes for us one of the qualities of Scipio, being opinion courage:

Art. Ne hercle operae pretium quidemst

mihi te narrare tuas qui virtutes sciam.

By Hercules! There is no reward for effort,

Then I will know your courage through your telling me who you are.

Perhaps Amphitruo 's previous passage Prologue is a reminder of Miles gloriosus ' prologue with regard to the concept of the term "courage" virtus. $^{(31)}$ 


\section{Ahmed FAHMY}

If Alcumena has courage virtus, and fears gods more than Amphitruo himself divis placitum (v.635), deum metum (v.841), at the same time we find her arranging the evidences and conjuring up the arguments for her husband Amphitruo, by using the same word "courage " virtute (v. 925):

Alc. Ego istaec feci verba virtute irrita.

Alc: by courage I refute those foolish words.

The position of Amphitruo in the play Amphitruo, reminds us of Scipio who was rewarded for his courage and victory inexplebilis virtutis (Liv. Ab Urbe Condita, 28.17.2 - 2):

ceteri laetitia gloriaque ingenti eam rem uolgo ferrent, unus qui gesserat, inexplebilis uirtutis.

In another form of happiness and great glory, they push plebeians towards the celebration, in particular, the person who managed (the battle) with highest courage.

Both Scipio and Amphitruo expect to be received as heroes, who return with honor honor, glory gloria and victory victoria ${ }^{(32)}$. So the word "courage" virtus is always associated with other words such as "glory" gloria and "luxury" luxuria, in pursuit of victory ${ }^{(33)}$, in this context Goldberg asserts that the use of the two words "courage" virtus and "glory" gloria in Roman comedy - especially in Plautus - it carries political significance through public practices in Rome ${ }^{(34)}$, where the courageous figure gains rewards and gifts for his courage, and this in itself represents glory for him. So in the play Amphitruo, Sosia refers that the hero Amphitruo has obtained the golden vessel for his courage in the battlefield (v. 260):

post ob virtutem ero Amphitruoni patera donata aurea est,

Then the master Amphitruo has been awarded the golden vessel because of his courage.

Amphitruo awarded this vessel to his wife Alcumena, asserting that he has obtained that vessel for his courage (v. 534):

nunc tibi hanc pateram, quae dono mi illi ob virtutem data est.

Now I award this vessel to you, this gift

which was given to me for courage. 


\section{- Moral and Political Significance of "Virtus" in Plautus' Amphitruo -}

Always the political meaning of the term "courage" virtus develops and appear among the warriors, keeping its military meaning ${ }^{(35)}$, so Plautus thinks that courage virtus is the base of evaluation to get the prize of victory (Amphitruo ,78):

virtute ambire oportet, non favitoribus.

the prize should be evaluated by courage, not by hireling supporters.

Since the glory gloria was the higher aim for the Roman, it was necessary that of the leader hero heros or the great warrior to have the courage to get this glory; this is because glory is more general than courage and comprehensive ; every courage is glory and not the opposite, which Plautus in the play Amphitruo indicated in Sosia 's description of the battle, where he presented to us Amphitruo as a hero, who combines all aspects of hospitality and honor for his courage and the courage of his soldiers (v.191192): ${ }^{(36)}$

id vi et virtute militum victum atque expugnatum oppidum est imperio atque auspicio eri mei Amphitruonis maxime.

That victory came by the strength and courage of the soldiers in taking

over the town, especially under the command and authority of my master Amphitruo.

This always reminds us of the opinion of Scipio's ring, who always emphasize the courage of their soldiers and their citizens in time of crisis (Liv, Ab Urbe Condita, 26.41.12.4):

in hac ruina rerum stetit una integra atque immobilis uirtus populi Romani.

meanwhile of this collapse of affairs the courage of the

Roman people has remained complete and deeply-rooted.

This courage to be achieved, it needs authority and leadership imperium atque auspicium, those that we touch at Livius, and is particularly associated with the ring of Scipio (Ab Urbe Condita , 28. 16. 14. 1-2): ${ }^{(37)}$

hoc maxime modo ductu atque auspicio P. Scipionis pulsi

Hispania Carthaginienses sunt. 


\section{Ahmed FAHMY}

In this way, Carthaginians are mainly in Spain under the leadership and authority of the struggler Scipio.

These previous verses are a tradition to the verse which Plautus mentioned in the play Amphitruo (v.657):

eos auspicio meo atque ductu primo coetu vicimus.

We have defeated them at the beginning of the attack under my leadership and authority.

It is clear from the two previous examples that the leadership and authority need courage virtus in order to achieve victory.

In conclusion, If morality is the social standard that the society produces to keep on its tenacity and firmness, this morality spread in the Roman society entices the spirit of courage and virtue virtus into society . So the Roman citizen through virtus can keep on the structure of his state without adherence to law , regulation or punishment, and then the Roman citizen may be refined and cultured socially and politically. if Scipio Africanus is responsible for the modification of traditional Roman ideas through the Greek effects, to produce a kind of Greco-Roman thought, or to show the Roman originality, hence Scipio is a model of courage virtus, therefore Plautus depends on the same term in the play Amphitruo to show to what extent does the Roman citizen have courage, which is represented in Amphituro's and Alcumena's characters .

\section{Notes}

(1) Ziskind, J.R.(1969), "Virtus in Republican and Imperial Rome " , Review of Politics 31, p.285 ; Adcock , F.E (1959), Roman political ideas and Practice , university of Michigan , pp.13-14.

For morality and policy in Republican age : Cf. Earl ,D .(1967), The Moral and Political Tradition of Rome, England, p.21ff .

(2) Earl ,D .(1967), pp.16-17.

(3) Earl, D.(1967) , p.12

(4) Ibid., pp.35-36.

(5) Segal, E.(1968), Roman Laughter, The Comedy of Plautus, Cambridge , p.56.

(6) Earl , D.(1967) , p.36.

(7) Beer , J.M.(1972), "A Mediaeval Cato - Virtus or virtue ? " Speculum 47 , p.59. Cf. Cato, Orationes ,58.14 ; Cato , De agri cultura ,1.2.5. 


\section{- Moral and Political Significance of "Virtus" in Plautus' Amphitruo •}

(8) Anderson ,W.S.(1995) , "The Roman Transformation of Greek Domestic Comedy", $C W$ vol.88, p.178.

(9) For Caesar's military courage: Cf. Brown , R.(2004) "Virtus Consili Expers “: An Interpretation of the Centurion's contest in Caesar, De Bello Gallico " , Hermes 132 , p.295.

${ }^{(10)}$ For the connection between consilium and virtus : cf. Brown , R.(2004), pp. 301-303 ; Adcock, F.E.(1959), pp.30 -31.

(11) Earl ,D.(1967), pp.19-20.

it seems that the emphasis on the word national courage virtus is definitely one of the Roman portrayal methods for dream somnium and achieving victory ; yet the earliest formula of courage concept always occurred in Ennius ' Annales, who viewed that this term was always pursued by the prominent character in the service of the state . and Plautus also depended on this concept in his play Amphitruo. This indicates that Ennius and Plautus were influenced by eloquence and rhetoric eloquentia, which Scipio was characterized by .

Cf. Galinsky ,G.K.(1966), "Scipionic Themes in Plautus' Amphitruo", TAPhA vol.97, p. 221; Earl , D.(1960) , " Political Terminology in Plautus ", Historia , p.239.

${ }^{(12)}$ Earl ,D.(1967), p.20.

(13) Ibid., p.34.

(14) Jameson, V.B.(1984), "Virtus Re-Formed : An Aesthetic Response Reading of Horace

, Odes III.II ", TAPhA vol.114, p. 222.

(15) Ibid., pp. 219.232

(16) Earl ,D.(1967), p.22.

(17) Cicero, Pro Sest. 143.

(18) For Sallust's concept of the term virtus " courage" and its connection with luxuria "luxury ":

Cf.Barbara ,W.B.(1987), "Virtus Effeminata and Sallust's Sempronia " , TAPhA 117, pp.185, 194-195.

(19) Earl ,D.(1967),p.34 ; Earl , D.(1960), Political Terminology , p.239.

(20) $\operatorname{Idem}(1960)$, p. 243.

(21) Segal ,E.(1968), p.22; Earl, D.(1960),p.239.

(22) Galinsky ,G.K.(1966), p.212.

${ }^{(23)}$ Earl ,D.(1967),pp.32-33.

(24) Galinsky ,G.K.(1966), p.212 ; Earl,D.(1960) , p.236.

(25) Earl,D.(1960) ,p.241.

(26) Galinsky, G.K.(1966), p.222.

(27) Phillips,J.E.(1985), " Alcumena in the Amphitruo of Plautus:A pregnant lady joke", $C J$ vol. 80 ,p.121.

(28) Ibid., pp.122, 126.

(29) Phillips, J.E.(1985), p.121.

(30) Christenson ,D (2001), "Grotesque Realism in Plautus "Amphitruo "" ,CJ 96 , pp.245, $249,250-251$.

(31) Galinsky ,G.K.(1966), p.218. 


\section{Ahmed FAHMY}

(32) Ibid., p.219.

(33). Earl ,D(1967), p.32.

(34) Goldberg , S.M.(1981) , "Scholarship on Terence and Fragments of Roman Comedy", CW $75, \mathrm{p} .88$.

(35) Frank, R.(1968), "Catullus 51 : otium versus virtus ", TAPhA 99, P.239.

(36) For the connection between virtus and gloria in Captivi (v.683 -689),(v.690):

cf. Earl, D.(1960), p.240.

(37) Galinsky ,G.K.(1966), p.219.

\section{Bibliography}

\section{Text Editions}

Cicero,M.T(1971) , Tusculanae Disputationes, edited by J.W King (L.C.L), Harvard University Press.

(1970), Orationes Pro Sestio in Vatinium , trans. by . R.Gardner, London.

Livy ,(1925), Ab Urbe Condita, edit. And trans. By( L.C.L) . London.

Plautus, T.M.(1988), edited by Paul Nixon, 5 Vols, (L.C.L), Harvard university Press .

Cato and Varo , (1934), on Agriculture, edit.by W.D.Hooper (L.C.L), London.

Horatius ,(1929), The Odes and Epodes, edit.and trans. By Bennett C.E., (L.C.L),London.

Sallustius, (1921), Historiarum fr. Ampliora, edit. By J.C.Rolfe ,(L.C.L) London.

\section{Books \& Articles}

Adcock, F.E (1959), Roman political ideas and Practice, university of Michigan .

Anderson ,W.S (1995), "The Roman Transformation of Greek Domestic Comedy", $C W 88$,pp.171-180.

Barbara ,W.B(1987), "Virtus Effeminata and Sallust's Sempronia ", TAPHA 117,pp.183-201.

Beer, J.M (1972), "A Mediaeval Cato - Virtus or virtue ? " speculum 47, pp.52-59. 


\section{- Moral and Political Significance of "Virtus" in Plautus' Amphitruo -}

Brown , R (2004) "Virtus Consili Expers “: An Interpretation of the Centurion's contest in Caesar, De Bello Gallico , Hermes 132 ,pp.292-308.

Christenson ,D (2001), "Grotesque Realism in Plautus ' Amphitruo ' " , CJ 96 ,pp.243-260.

Cicero , Tusculam Disputations, Edited by J.W King (L.C.L), Harvard Uni., (1971).

Earl ,D (1967), The Moral and Political Tradition of Rome ,England. (1960), "Political Terminology in Plautus ", Historia ,pp.235-243.

$\overline{\text { Frank }}$, R (1968), "Catullus 51 : otium versus virtus ", TAPHA 99 , pp.233-239.

Galinsky ,G.K (1966), "Scipionic Themes in Plautus' Amphitruo" , TAPHA 97 ,pp.203-235.

Goldberg, S.M (1981), Scholarship on Terence and Fragments of Roman Comedy , $C W 75$,pp.77-115.

Jameson, V.B(1984), Virtus Re-Formed : An Aesthetic Response Reading of Horace, Odes III.II, TAPHA 114 , pp. 219-240.

Phillips,J.E(1985) ," Alcumena in the Amphitruo of Plautus:A pregnant lady joke ", CJ 80 ,pp.121-126.

Plautus, Edited by Paul Nixon, 5 vols, (L.C.L), Harvard university Press (1988).

Segal, E (1968), Roman Laughter, The Comedy of Plautus, Cambridge.

Ziskind, J.R (1969), ," Virtus in Republican and Imperial Rome ", Review of Politics 31,p.285. 